Article

\title{
Land-Cover Patterns and Hydrogeomorphology of Tributaries: Are These Important Stressors for the Water Quality of Reservoirs in the Mediterranean Region?
}

\author{
Patrícia Palma ${ }^{1,2, *} \mathbb{0}$, Sofia Fialho ${ }^{1}$, Ana Lima ${ }^{1}$, Clarisse Mourinha ${ }^{1}$, Alexandra Penha ${ }^{2}{ }^{\oplus}$, \\ Maria Helena Novais 2,3 ${ }^{\mathbb{D}}$, Anabela Rosado ${ }^{2}$, Manuela Morais ${ }^{2,4}$, Miguel Potes ${ }^{2}$ (D), \\ Maria João Costa ${ }^{2,4}$ (D) and Paula Alvarenga ${ }^{5}$ (D) \\ 1 Department of Technologies and Applied Sciences, Polytechnic Institute of Beja, 7801-295 Beja, Portugal; \\ sofiafialho16@gmail.com (S.F.); ana.filipa.lima89@gmail.com (A.L.); clarisse.mourinha@ipbeja.pt (C.M.) \\ 2 ICT, Institute of Earth Sciences, University of Évora, Rua Romão Ramalho 59, 7000-671 Évora, Portugal; \\ mapenha@uevora.pt (A.P.); hnovais@uevora.pt (M.H.N.); arosado@uevora.pt (A.R.); \\ mmorais@uevora.pt (M.M.); mpotes@uevora.pt (M.P.); mjcosta@uevora.pt (M.J.C.) \\ 3 Renewable Energies, University of Évora, Casa Cordovil, Rua D. Augusto Eduardo Nunes n 7, Évora, \\ 7000-651, Portugal \\ 4 Science and Technology School, University of Évora, 7000-671 Évora, Portugal \\ 5 Linking Landscape, Environment, Agriculture, and Food Research Unit (LEAF), Instituto Superior de \\ Agronomia, Universidade de Lisboa, Tapada da Ajuda, 1349-017 Lisboa, Portugal; palvarenga@isa.ulisboa.pt \\ * Correspondence: ppalma@ipbeja.pt; Tel.: +35-12-8431-4300
}

Received: 10 September 2020; Accepted: 21 September 2020; Published: 23 September 2020

\begin{abstract}
Four streams in the Guadiana watershed were followed up to assess hydrogeomorphological and physicochemical characteristics, and to analyze its correlation with land use/land cover (LULC), analyzing their possible influence in reservoir water quality and possible influence in the reservoir water quality. The highest amounts of organic descriptors and nutrients were quantified in streams with the major percentage of olive groves and vineyards and urban land cover classes. Streams more influenced by agro-silvo-pastoral class presented better water quality, as this type of LULC acts as a buffer of the contamination runoff. The results highlighted that the hydrogeomorphology of the streams may influence the transfer of pollutants loads to reservoirs. Hence, in intermittent streams characterized by coarse particles in the sediment, high amounts of pollutants are accumulated when the flow ceases, and are further transported to the reservoirs when the flow retakes. On the contrary, streams with sediments characterized by a great percentage of fine particles and organic matter do not induce so much stress in reservoirs, since these allow the adsorption of nutrients and trace elements, without their transfer to reservoirs.
\end{abstract}

Keywords: flow regime; hydrogeomorphology; water quality assessment; land use/land cover (LULC); Guadiana watershed

\section{Introduction}

Degradation of ecosystems at different spatial and temporal scales occurs through multiple stressors, resulting in a loss of biodiversity and in an impoverishment of ecosystem services [1]. Aquatic systems are among the most sensitive, exposed, and degraded habitats, due to societal demands for food, drinking water, transport, power generation, and leisure activities [2,3]. Thus, water scarcity, along with water quality problems, have become two of the most important threats 
for the sustainability of aquatic ecosystems in semi-arid areas [4]. This situation becomes much more worrying in regions where the water scarcity is a serious problem, with the Mediterranean being one of the most vulnerable regions to the increasing pressure on water resources $[5,6]$.

To overcome water shortage problems, dams were constructed, and their water quality assessment became crucial, not only to establish management actions to preserve their quality but also to prioritize rehabilitation processes. This assessment should encompass the water spatial and temporal variability and the identification of the main limnological factors that regulate the system, as the most important stressors that induce the highest environmental and public health concerns [7-11]. For a more efficient and integrative catchment management, it is also crucial to have knowledge about the inputs to the water bodies, from point and non-point sources of pollution, including the contribution from their tributaries [12-14]. Hence, developing studies in tributaries of reservoirs with a great flow variability as in Mediterranean region, and significantly influenced by land use/land cover (LULC), may contribute to identify the streams that strongly influence the water quality of reservoirs along time, essential to implement and improve watershed management measures [15].

In fact, LULC patterns are one of the main factors affecting water quality and ecosystems balance in a watershed [16]. As in many other regions, where the construction of dams induced an increment of economic activities [17], LULC changes have occurred in Alentejo (Southern Portugal) after the construction of the Alqueva Dam, mainly in the agricultural sector with the intensification of olive groves and vineyards and modification of the agricultural practices [18].

Several studies have been developed at the Alqueva reservoir, to evaluate limnological factors, biodiversity, point and non-point sources of pollution, and atmospheric processes, such as: (i) water quality and spatial-temporal variability $[8,19,20]$; (ii) nutrients and eutrophication processes [21]; (iii) biological communities and biodiversity [22-27]; (iv) quantification and risk assessment of hazardous substances, such as pesticides and potential toxic metals [28-31]; (v) remote sensing-based prediction of water quality and atmospheric processes [32,33]; and (vi) ecotoxicological assessment [34,35].

Currently, it is important to understand the linkage among tributaries and the Alqueva reservoir, to understand the effect of temporary regimes and geomorphological characteristics in the water quality of the reservoir, as well as the effect of LULC changes in the catchment, an understudied aspect, since intermittent streams have only recently gained scientific attention.

Taking the above statements into consideration, the aims of this study were to: (1) characterize the hydrogeomorphology of streams in the Guadiana watershed and LULC in the respective drainage areas; (2) assess the spatial and temporal chemicals dynamics of water and sediment; (3) analyze the correlations between water/sediments characteristics and LULC patterns; and (4) analyze the possible influence of streams hydrogeomorphology, chemical characteristics and LULC at the drainage areas in the water quality of the reservoir. To understand the relationship between landscape, hydrogeomorphological characteristics, and water quality, further improving water contamination estimations in catchments and providing tools to establish guidelines for land use/land cover (LULC) planning.

\section{Materials and Methods}

\subsection{Study Area}

The Alqueva reservoir is located in the main course of Guadiana river, and is the most important source of water supply for the populations of the Alentejo region (Southern Portugal), which is one of the driest regions in Portugal, with a Mediterranean climate [32], and where the agriculture is one of the most important economic activities [18].

The study was developed in four streams of the Guadiana watershed: Zebro (Zb; 38 $14^{\prime} 15.5^{\prime \prime} \mathrm{N}$,

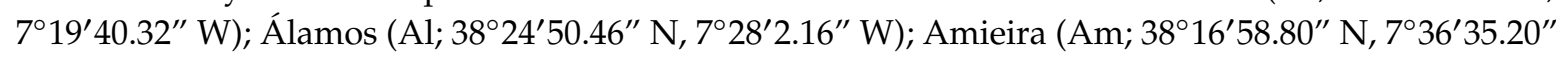
W), and Lucefécit (Lf; $38^{\circ} 36^{\prime} 59.19^{\prime \prime}$ N, $7^{\circ} 23^{\prime} 31.65^{\prime \prime}$ W) (Figure 1). In the framework of the ALOP project 
(observation, prediction, and alert systems in atmosphere and in water reservoirs of Alentejo), four platforms previously installed in diverse limnetic areas of the reservoir were used to assess four areas of the reservoir. These platforms consist in floating structures fixed to the bottom of the reservoir with cables, used for sampling, to characterize the water quality, and where meteorological devices were installed. These streams were chosen considering their flow into the Alqueva reservoir towards each platform: Zebro drains into the reservoir near the Montante platform; Álamos near Mourão platform; Amieira near Álamos platform; and Lucefécit near Lucefécit platform (see Figure 1).

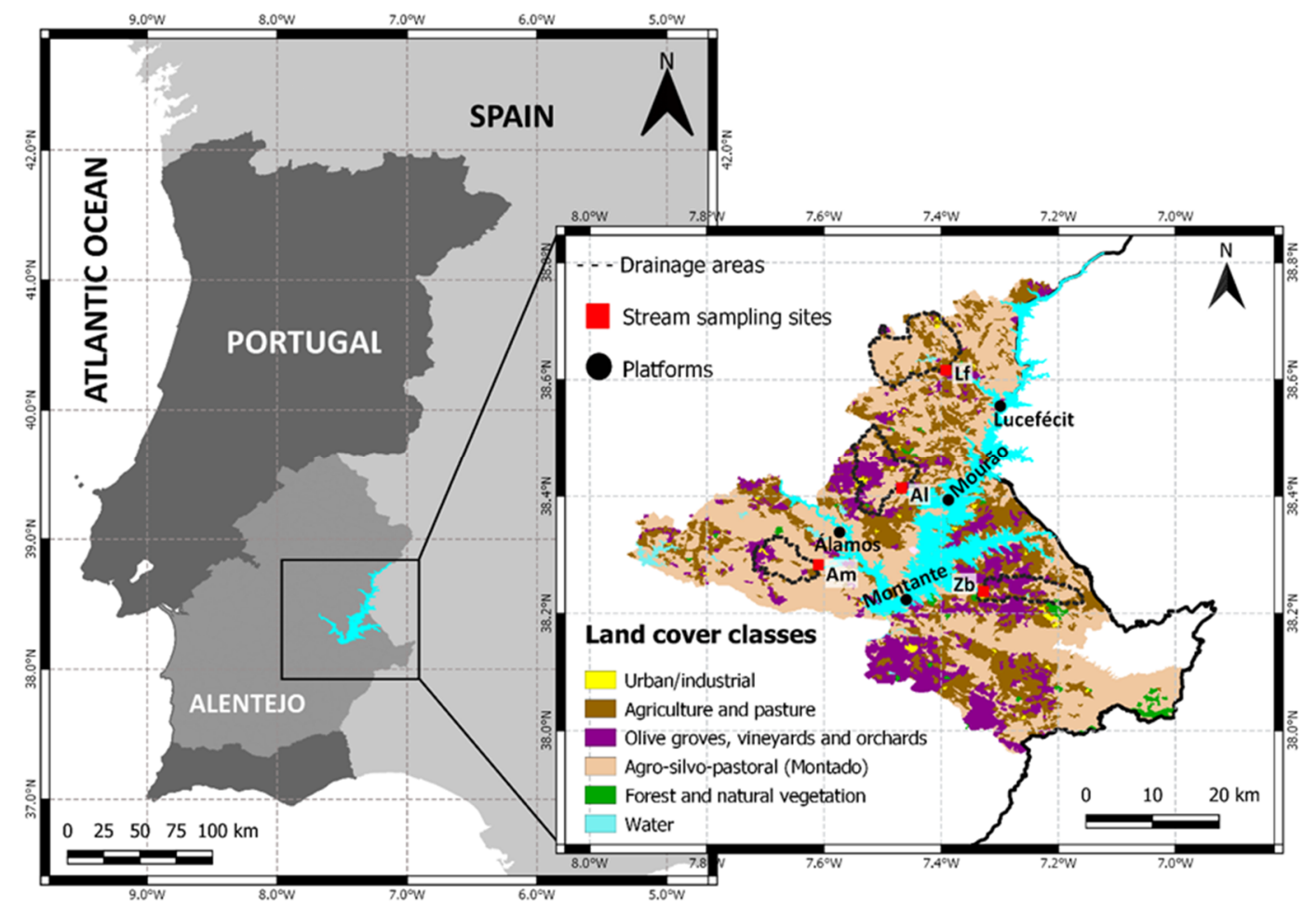

Figure 1. Map of the study area located in Alentejo region, with the municipalities that embrace Alqueva reservoir represented in the land cover zoomed map. The stream sampling sites from north to south are: Lucefécit—Lf; Álamos—Al; Amieira-Am; and Zebro-Zb).

With the increase and expansion of the irrigation system in the area, there has been a growth of intensive crops in a region traditionally occupied by agro-forestry systems (Montado), where urban areas have very little expression. The agricultural occupation in the irrigation perimeters of Alqueva has been diversifying, with olive groves as the predominant cultivation. Peanut is the second crop with the greatest expression in terms of farmers' bet. The production of almonds, corn, tomatoes, onions, garlic, melons, watermelons, and fruit trees (stone fruit, citrus fruits, table grapes, walnuts, among others), are also found in the irrigated areas of Alqueva, alongside the traditional cultivation of vines, cereals and fodder ((Empresa de Desenvolvimento e Infra-estruturas do Alqueva, S.A. (EDIA): https://www.edia.pt, last accessed on 3 September 2020)).

The studied streams are small and shallow watercourses, belong to the small drainage area rivers in Southern Portugal (S1 $\leq 100 \mathrm{~km}^{2}$ ) according to the Water Framework Directive river typology [36], and are located in sites with siliceous lithology, with the studied reaches mainly characterized by: bank-full channel width ranging from 1-5 $\mathrm{m}$ in Álamos and Amieira to 5-10 $\mathrm{m}$ in Lucefécit and Zebro; the mean channel width from $<1 \mathrm{~m}$ in Álamos to 1-5 $\mathrm{m}$ in the other sites, and channel depth ranging from $<0.25 \mathrm{~m}$ to $0.5 \mathrm{~m}$ in Álamos, $<0.25 \mathrm{~m}$ to $1 \mathrm{~m}$ in Amieira, $0.25 \mathrm{~m}$ to $1 \mathrm{~m}$ in Zebro, and only in Lucefécit the depth exceeded $1 \mathrm{~m}$ after a flooding in March 2018, whilst in the other sampling campaigns was between $<0.25 \mathrm{~m}$ to $0.5 \mathrm{~m}$. The riparian vegetation is continuous in Amieira stream, 
semi-continuous in Lucefécit and Álamos and scattered in Zebro stream; furthermore, there is no shadow in the channel in Zebro and in Álamos, opposite to Lucefécit where more than $60 \%$ of the stretch is shadowed and in Amieira with a shadow between 30-60\%. Amieira and Álamos are typical Mediterranean intermittent watercourses that dry or stop flowing during part of the year (only small isolated pools are present in summer, namely in July and September), whilst Zebro has no flow during summer and Lucefécit maintains flow during all the year, despite a substantial reduction during the summer. The main characteristics observed in each stream are summarized in Table S1. The four studied streams are subject to some anthropogenic impacts, both in the banks and in the channels, such as small bridges in Zebro and Álamos and upstream of Lucefécit sampling stretch, cattle raising in Amieira, Zebro, and Álamos, wastewater treatment plants upstream the sampling sites in Zebro and Álamos and intensive agriculture in the banks of Lucefécit sampling stretch. A detailed analysis of the LULC in each of the four tributaries is presented in Section 2.2.

The Mediterranean climate is characterized by dry and hot summers and temperate and wet winters, with concentrated rainfalls [37]. During the year of 2017, the onsite meteorological station [38] provided an annual average temperature of $17.8^{\circ} \mathrm{C}$, ranging from a minimum temperature of $-1.8^{\circ} \mathrm{C}$ in January to a maximum of $45.2^{\circ} \mathrm{C}$ in August, with an annual precipitation of $327.8 \mathrm{~mm}$. As for the year of 2018 , the climate was characterized by an average temperature of $16.3^{\circ} \mathrm{C}$ ranging from $-1.8^{\circ} \mathrm{C}$ in February to $44.7^{\circ} \mathrm{C}$ in August, with an annual precipitation of $665.8 \mathrm{~mm}$. Meteorological drought monitoring is performed by the Portuguese Institute for the Sea and Atmosphere (IPMA), using the Palmer Drought Severity Index (PDSI). The South of Portugal was considered in severe drought conditions, from April 2017 on, registering the highest temperatures observed in the last 80 years, and with the smallest precipitation values [39], whereas the year of 2018 was considered normal by IPMA regarding air temperature and rainfall, with the severe drought situation ending in March 2018. Furthermore, the precipitation was concentrated in storms, which may cause streams to flood.

\subsection{LULC Characterization}

The basis for the LULC analysis carried out for the area of study was the CORINE Land Cover (CLC) inventory produced in 2018 using satellite imagery (Sentinel-2 and Landsat-8 for gap filling), available from Copernicus Land Monitoring Service (https://land.copernicus.eu/pan-european/corineland-cover/). The CLC inventory uses a minimum mapping unit of 25 ha for area phenomena and a minimum width of $100 \mathrm{~m}$ for linear phenomena and distinguishes 44 land cover classes (https://www.eea.europa.eu/publications/COR0-landcover). The analysis showed that 24 out of the 44 CLC classes are present in the area of study. These 24 classes were merged to yield six broader categories describing typical LULC in the region: urban/industrial; agriculture and pasture; olive groves, vineyards and orchards; agro-silvo-pastoral (Montado); forest and natural vegetation; water. Table S2 summarizes the integration of CLC classes into the adopted categories. The agro-silvo-pastoral class corresponds to a very typical landscape of southern Portugal termed Montado, characterized as a multifunctional agro-silvo-pastoral ecosystem, with varying densities of trees (mainly cork and/or holm oaks). The Montado system encompasses more than one CLC class due to its particularities [40], as indicated in Table S2.

The adopted classification considering the six classes was applied to the region comprising the five Portuguese municipalities surrounding Alqueva reservoir (Alandroal, Moura, Mourão, Portel, and Reguengos de Monsaraz). The resulting land cover map is presented in Figure 1, showing that Montado landscape dominates the region, with significant parts of the area also occupied by olive groves, vineyards and orchards, as well as, agriculture and pasture.

ASTER Global Digital Elevation Model (GDEM) V002 (ASTER GDEM is a product of NASA and METI) data were used to obtain the area of drainage basins associated to each of the sampling (outlet) points. The DEM data were obtained from the Land Processes Distributed Active Archive Center (LP DAAC: https://gdex.cr.usgs.gov/gdex/) in a grid of 1 arc-second (approximately $30-\mathrm{m}$ at the 
equator). The drainage basins of stream sampling points represent the appropriate areas to analyze and relate land cover to water quality, since these collect and drain off surface and ground water, as well as precipitation into the control point. The altitudes in the four drainage basins range between 141 and $416 \mathrm{~m}$ above mean sea level (a.m.s.l). The drainage basins delineated from DEM data are represented by the dotted black lines in Figure 1.

\subsection{Sampling}

Water and sediment samples were collected at the four selected streams (Lucefécit-Lf; Álamos-Al; Amieira-Am; and Zebro-Zb). The study comprised 12 sampling campaigns, from January 2017 to November 2018: in January (Jn), March (Mr), May (M), July (Jl), September (Sp), and November (Nv). The intermittency nature (with highly irregular flowing regime) of these streams in Mediterranean areas, justified the temporal evaluation proposal. In these regions, the stream discharges may range from zero (dry phase) to high discharge rates (flooding period). This river flow regime has implications in the water quality and makes the streams very sensitive to anthropogenic pressures [19].

In general, the sampling occurred in flowing conditions, except at Amieira in July and September 2017 and 2018 and at Álamos in July and September 2018 (dry phase), collected in an isolated pool upstream of the regular sampling sites. Sampling at each site included: (i) 2 L of surface water in polyethylene bottles, for the analysis of physicochemical parameters; and (ii) $5 \mathrm{~L}$ of surface sediments $(<10 \mathrm{~cm})$ on plastic bags. The samples were transported to the laboratory at $4{ }^{\circ} \mathrm{C}$, conserved and stored until the analysis following the requisites for each parameter $[41,42]$.

\subsection{Water Characterization}

Water temperature $\left(\mathrm{T} ;{ }^{\circ} \mathrm{C}\right), \mathrm{pH}$, electrical conductivity $\left(\mathrm{EC} ; \mu \mathrm{S} \mathrm{cm}{ }^{-1}\right)$, and dissolved oxygen (DO; \%) were measured in situ using a multiparametric YSI 6820 MPS probe ${ }^{\circledR}$ (Alemanha, Portugal).

The water parameters analyzed were the following: biochemical oxygen demand $\left(\mathrm{BOD}_{5} ; \mathrm{mg} \mathrm{L}^{-1}\right.$; respirometric method), chemical oxygen demand (COD; $\mathrm{mg} \mathrm{L}^{-1}$; dichromate technique), total phosphorus (TP; mg L ${ }^{-1}$; molecular absorption spectrometry), Kjeldahl nitrogen (KN; $\mathrm{mg} \mathrm{L}^{-1}$; molecular absorption spectrometry), nitrate $\left(\mathrm{NO}_{3} ; \mathrm{mg} \mathrm{L} \mathrm{L}^{-1}\right.$; Ionic chromatography), nitrite $\left(\mathrm{NO}_{2}\right.$; $\mathrm{mg} \mathrm{L}{ }^{-1}$; ionic chromatography), ammonium $\left(\mathrm{NH}_{4} ; \mathrm{mg} \mathrm{L}^{-1} ;\right.$ molecular absorption spectrometry), chlorides ( $\mathrm{Cl} ; \mathrm{mg} \mathrm{L}^{-1}$; ionic chromatography), and sulfates $\left(\mathrm{SO}_{4} ; \mathrm{mg} \mathrm{L}^{-1}\right.$; Ionic chromatography) [41].

Total nitrogen (TN) was determined, using the following Equation (1) [41]:

$$
\mathrm{TN}\left(\mathrm{mg} \mathrm{L}^{-1}\right)=0.226 \times\left[\mathrm{NO}_{3} ; \mathrm{mg} \mathrm{L}^{-1}\right]+0.304 \times\left[\mathrm{NO}_{2} ; \mathrm{mg} \mathrm{L}^{-1}\right]+\left[\mathrm{KN} ; \mathrm{mg} \mathrm{L}^{-1}\right]
$$

\subsection{Sediment Characterization}

As for the sediments, the $\mathrm{pH}\left(\mathrm{pH}_{\text {pore-water }}\right)$ and the electrical conductivity $\left(\mathrm{EC}_{\text {pore-water }} \mu \mathrm{Cm}^{-1}\right)$ were analyzed in pore-water samples [42].

Sediment grain-size distribution was determined following the method E196 of the Portuguese Laboratory of Civil Engineering [43]. The chemical parameters determined were: organic matter content (OM; \%; calcination at $500{ }^{\circ} \mathrm{C}$; [42]); total nitrogen (TN; \%; Kjeldahl method; [41]); total phosphorus (TP; \%; molecular absorption spectrometry with molybdovanadate phosphoric acid; [41]).

Potentially hazardous trace elements contents $(\mathrm{Cd}, \mathrm{Cr}, \mathrm{Cu}, \mathrm{Ni}, \mathrm{Pb}$, and $\mathrm{Zn}$ ) were determined according to International Organization for Standardization (ISO) 11466 [44]. Flame atomic absorption spectrometry (FAAS) was used in the analysis, by a Varian equipment (SpectrAA 220FS, 220Z and 110Z, Palo Alto, CA, USA).

\section{Quality Control}

The quality of the analytical data was guaranteed through the implementation of laboratory quality assurance, as the use of standard operating procedures, calibration with standards, analysis of blanks and of replicates (three independent replicates per sample). 
For the validation of the analytical procedures of the potentially hazardous trace elements quantification, a geological certified reference material, Buffalo Lake sediment (SRM 2704), was analyzed to validate the aqua regia extraction procedure. The assessment among reference material and the samples presented a mean relative error $<10 \%$, for all the elements analyzed $(\mathrm{Cd}, \mathrm{Cr}, \mathrm{Cu}, \mathrm{Ni}$, $\mathrm{Pb}$, and $\mathrm{Zn})$.

\subsection{Statistical Treatment of Data}

Water and sediments data were assessed by descriptive statistics (mean \pm standard deviation) and multivariate statistical analysis (principal component analysis/factor analysis and cluster analysis), based on two matrixes, one for water (48 samples $\times 13$ environmental parameters), and another for sediments (48 samples $\times 12$ environmental parameters). Data were normalized ( $\log x ; \mathrm{x}=$ mean value) prior to multivariate statistical analyses, avoiding misclassification due to differences in data dimensionality [45].

Spearman's rank coefficient correlations between variables were performed (since most of the data failed the Shapiro-Wilk normality test), and the Spearman coefficient (R) was used to evaluate the statistical strength of the correlations, obtained by the potential linear relationship between the classes of land cover and the environmental variables.

Principal component analysis/factor analysis (PCA/FA) and cluster analysis (CA) were applied to: (1) identify the main parameters that explain the variability of the stream water quality; (2) group the streams according to their water quality; (3) group the streams according to the land cover; and (4) identify the streams that may have the greatest influence on the Alqueva reservoir water quality.

The CA groups the most similar samples, using the Euclidean distance between samples as a measurement of similarity [46]. The linkage distance is obtained through the following Equation (2):

Dlink/Dmax (Dlink: linkage distance for an individual case; Dmax: maximum linkage distance).

All statistical analyses were performed with the STATISTICA 7.0 (Software ${ }^{\text {TM }}$ Inc., Palo Alto, CA, USA, 2004).

\section{Results}

\subsection{LULC Description}

The LULC patterns were analyzed in the drainage areas delimited for each of the stream sampling sites, corresponding to the following areas: Álamos-89.0 km² Amieira- $50.8 \mathrm{~km}^{2}$, Lucefécit- $117.2 \mathrm{~km}^{2}$, and Zebro- $46.8 \mathrm{~km}^{2}$, from which we calculated the percentages of LULC classes. Figure 2 shows the percentages obtained for each class within the considered catchments. Notice that the agro-silvo-pastoral class dominates in three of the four drainage areas (Álamos, Amieira, and Lucefécit with $43 \%, 73 \%$, and $67 \%$, respectively), which reflects the prevalence of this type of landscape in the region. In Lucefécit stream, agriculture and pasture class follows with $28 \%$, whereas in Álamos and Amieira, the olive groves, vineyards, and orchards is the second class with $33 \%$ and $17 \%$, respectively. Furthermore, while Álamos presents also a fairly significant amount of agriculture and pasture (22\%), in Amieira this class is barely $8 \%$. In Zebro drainage basin, the olive groves, vineyards, and orchards is the leading class $(42 \%)$, followed by agriculture and pasture $(31 \%)$. It is important to refer that Lucefécit drainage area is the only one including industrial activities (extractive and food processing, among others). 


\subsection{Stream Water Characterization}

\subsubsection{In Situ Parameters}

Water quality varied markedly among streams, influenced by different LULC classes and by the temporal variability (Figures 3 and 4). Relatively to the results for the in situ parameters (Figure 3), the water $\mathrm{pH}$ presented low variability in all the streams with values always between the limits proposed for the good ecological status (GES) for small rivers of Southern Portugal $(6 \leq \mathrm{pH} \leq 9$; [47]). The temperature changed markedly among seasons with values in the wet period from 6.5 to $15^{\circ} \mathrm{C}$ and in the dry period from 17 to $34^{\circ} \mathrm{C}$, with the highest values registered at Amieira in 2018, when the stream was in its dry phase. The dissolved oxygen (DO), also showed a great temporal variability, with saturation percentages exceeding the limits for the good ecological status (60-120\%; [47]) at Amieira, in January and July 2017 (DO = 181\%), at Álamos in January 2017 (DO = 125\%), and at Zebro in July 2017 (DO = 171\%). In general, the DO variations are related with seasonal changes and rainfall patterns, being the higher values observed during the wet season $[7,8,48]$, which may explain the high levels detected in January, characterized by low water temperature. The electric conductivity (EC) was the parameter that presented the major variability among streams, with the highest values $(>1000 \mu S$ $\mathrm{cm}^{-1}$ ) detected at Zebro and Álamos. In the present study, the EC was correlated with the LULC of olive groves, vineyards and orchards $(R=0.42 ; p<0.05$; Table S3), which dominates at Zebro stream $(42 \%)$ and is the second one at Álamos (33\%), followed in both drainage areas by the agriculture and pasture class, occupying $31 \%$ and $22 \%$, respectively (see Figure 2).

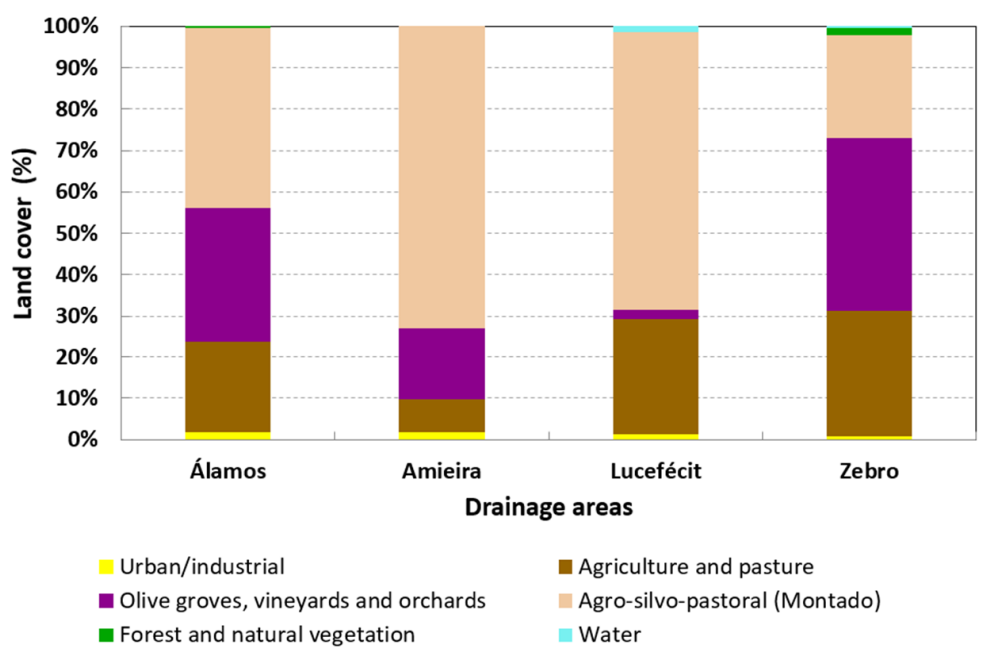

Figure 2. Percentages of the land use/land cover (LULC) classes in the selected drainage areas.

\subsubsection{Nutrients and Organic Descriptors}

Spearman rank coefficient (Table S3) showed positive correlations among $\mathrm{T}$ and EC, BOD, $\mathrm{COD}$ $\mathrm{TP}, \mathrm{NO}_{3}$ and $\mathrm{NH}_{4}$, indicating that these parameters were the major source of temporal variability in the streams.

Regarding the organic descriptor $\mathrm{BOD}_{5}$ (Figure 4), the concentrations were above the limit for the good ecological status $\left(\mathrm{BOD}_{5} \leq 6 \mathrm{mg} \mathrm{L}^{-1}\right.$; [36]) at Zebro and Álamos, during most of the study. The results obtained seem to be linked with LULC, once the presence of $\mathrm{BOD}_{5}$ at watercourses is correlated with the increment of olive groves, vineyards, and orchards area $(R=0.40 ; p<0.05)$, impact more evident during the dry period. Further, the positive correlations between $\mathrm{BOD}_{5}$ and TP $(R=0.41$; $p<0.05), \mathrm{TN}(R=0.48 ; p<0.05)$, and $\mathrm{NH}_{4}(R=0.59 ; p<0.05)$ indicate similar sources of pollution, also supported by the linkage obtained between these parameters and the LULC class of olive groves, vineyards and orchards (Table S3). All streams presented concentrations of COD greater than 20 $\mathrm{mg} \mathrm{L}^{-1}$, limit value established for water bodies in risk [49]. In fact, concentrations of BOD 5 and COD, 
above $5 \mathrm{mg} \mathrm{L}^{-1}$ and $20 \mathrm{mg} \mathrm{L}^{-1}$, respectively, indicate a high organic load, which may be responsible for the degradation of ecological conditions.

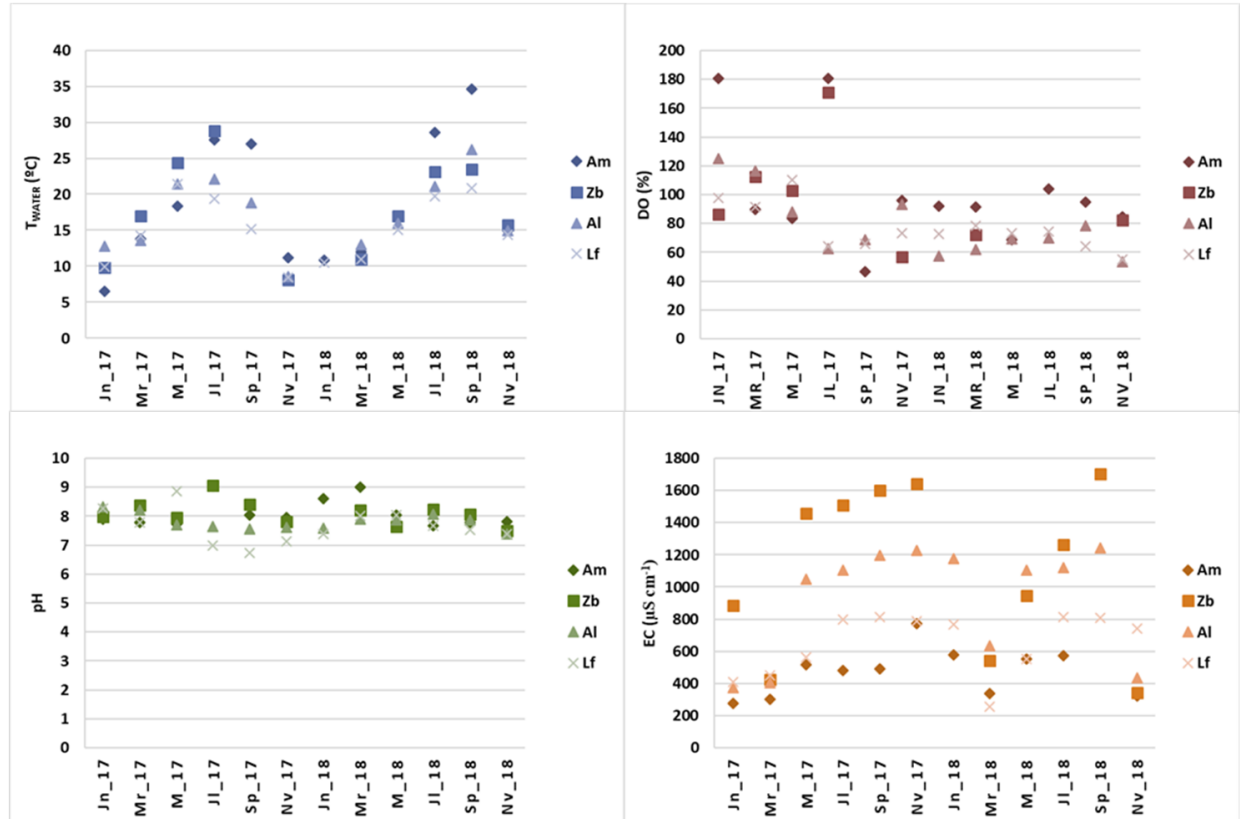

Figure 3. Parameters measured in situ, in each stream (Zb: Zebro; Am: Amieira; Al: Álamos: Lf: Lucefécit), during the 12 campaigns of the study (Jn_17: January 2017; Mr_2017: March 2017; M_2017: May 2017: J1_2017: July 2017: Sp_2017: September 2017; Nv_2017: November 2017; Jn_18: January 2018; Mr_2018: March 2018; M_2018: May 2018: J1_2018: July 2018: Sp_2018: September 2018; Nv_2018: November 2018).

The total nitrogen (TN) presented the highest concentrations at Zebro (0.69-29.89 $\left.\mathrm{mg} \mathrm{L}^{-1}\right)$ and Álamos $\left(0.66-21.60 \mathrm{mg} \mathrm{L}^{-1}\right)$, without a pronounced temporal pattern, probably related with the hydrogeomorphology and LULC (Figures 2 and 4). Results highlighted by the positive correlation observed between TN and olive groves, vineyards and orchards class $(R=0.32 ; p<0.05)$ and by the negative correlation with the class of agro-silvo-pastoral $(R=-0.43 ; p<0.05)$. Indeed, the Amieira stream, with a predominance of agro-silvo-pastoral class (73\%), is the stream with the best water quality, during the flowing phase. Relative to $\mathrm{NH}_{4}$, this parameter reached concentrations higher than $1 \mathrm{mg} \mathrm{L}^{-1}$ at Zebro (limit for the good ecological status; [36]). These results were influenced by the temporal factor (higher amounts in the dry period with low flow), and by the LULC (olive groves, vineyards and orchards class), and supported through the correlation between $\mathrm{NH}_{4}$ and this class of LULC $(R=0.46 ; p<0.05)$. Furthermore, the correlation between $\mathrm{NH}_{4}$ and urban/industrial LULC $(R=0.49 ; p<0.05)$, also indicates the influence of this class in the increment of nutrients in streams. Total phosphorus (TP) presented always values higher than $1 \mathrm{mg} \mathrm{L}^{-1}$, being responsible for the failure to comply with the good ecological status of the streams, both in the wet and dry periods $\left(0.13 \mathrm{mg} \mathrm{L}^{-1}\right.$; [47]). The results showed that the increase of TP at streams was correlated with olive groves, vineyards and orchards LULC $(R=0.56 ; p<0.05)$. 

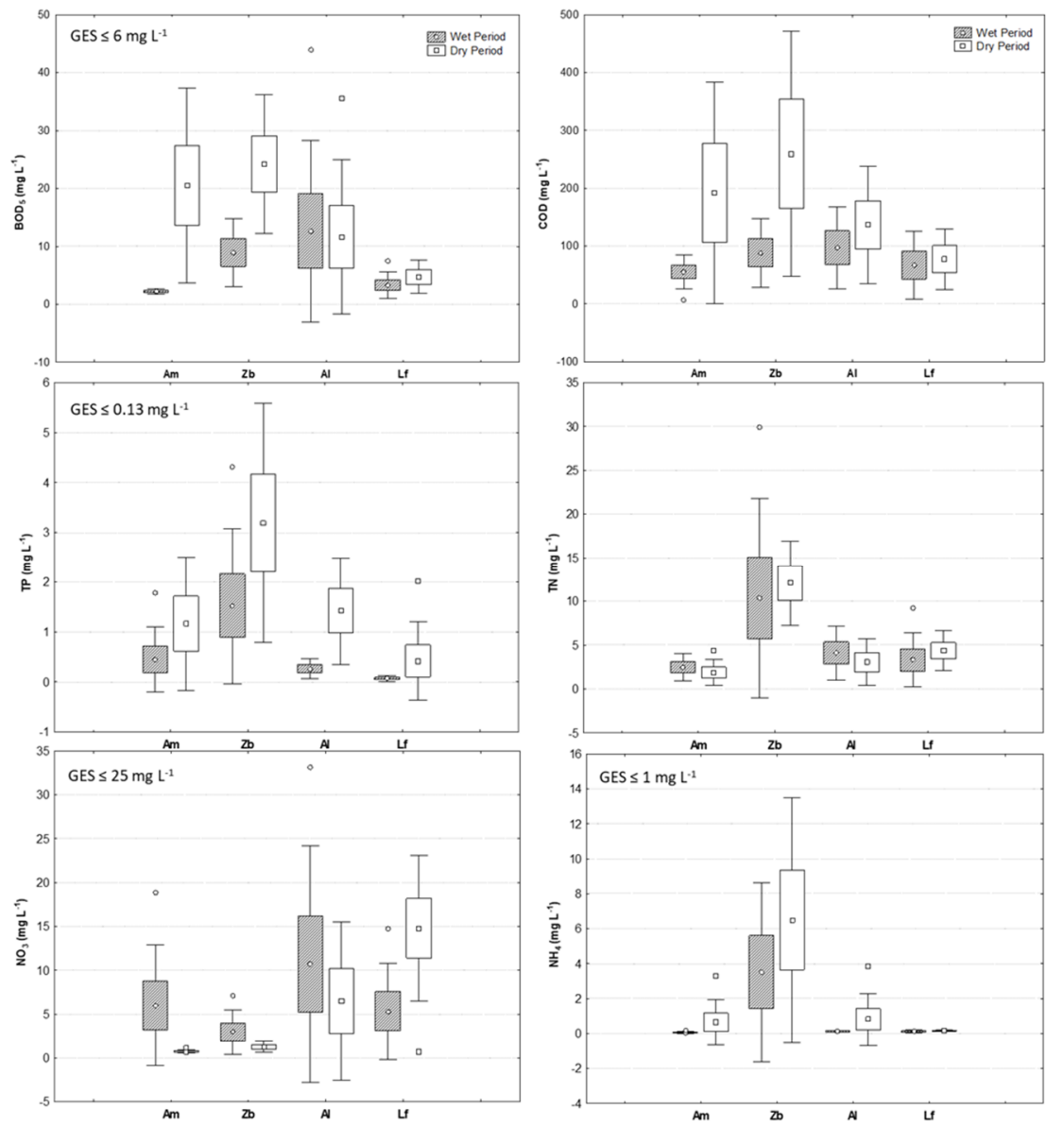

Figure 4. Spatial and temporal variation of the organic descriptors and nutrients in the water samples during the period of the study. The mark across the box represents the mean, and the bottom and top of the box show the standard deviation. Whenever possible, recommended guide levels for the good ecological status (GES) were represented [47].

\subsubsection{The Effect of LULC and Hydrogeomorphology on the Water Quality}

PCA was conducted using pooled data from the four streams, allowing the identification of two principal components (PCs) as important factors to explain $45 \%$ of the total variance of the water samples. Figure 5 shows the combined plot of scores and loadings on PC1 versus PC2. The PC1 represented the influence of LULC classes (urban/industrial; olive groves, vineyards and orchards, and agro-silvo-pastoral (Montado)) on the physico-chemical composition of water explaining 29\% of the variance. This $\mathrm{PC}$ was highly associated with $\mathrm{TN}, \mathrm{NH}_{4}$, and $\mathrm{Cl}$ (negative participation) and moderately associated with $\mathrm{NO}_{2}$ (negative participation). Hence, this $\mathrm{PC}$ is explained considering the nutrient discharges at streams under the influence of LULC classes of olive groves, vineyards, and orchards and urban/industrial (also negatively correlated with the PC). Further, the PC1 presented a positive correlation with flow characteristics $(R=0.35 ; p<0.05)$, grouped in four classes (see Table S1: no flow, low flow, moderate flow, very fast flow). The LULC that explained PC2 was agriculture and pasture class, representing $16 \%$ of the variance with a strong negative participation of TP and a moderate participation of $\mathrm{NO}_{3}$ (positive) and $\mathrm{BOD}_{5}$ (negative). Moreover, this $\mathrm{PC}$ presented a positive correlation with flow characteristics $(R=0.52 ; p<0.001)$. The positive correlation of both PC with the flow indicate the importance of this parameter in the transport of nutrients along the streams and downstream to reservoirs. 


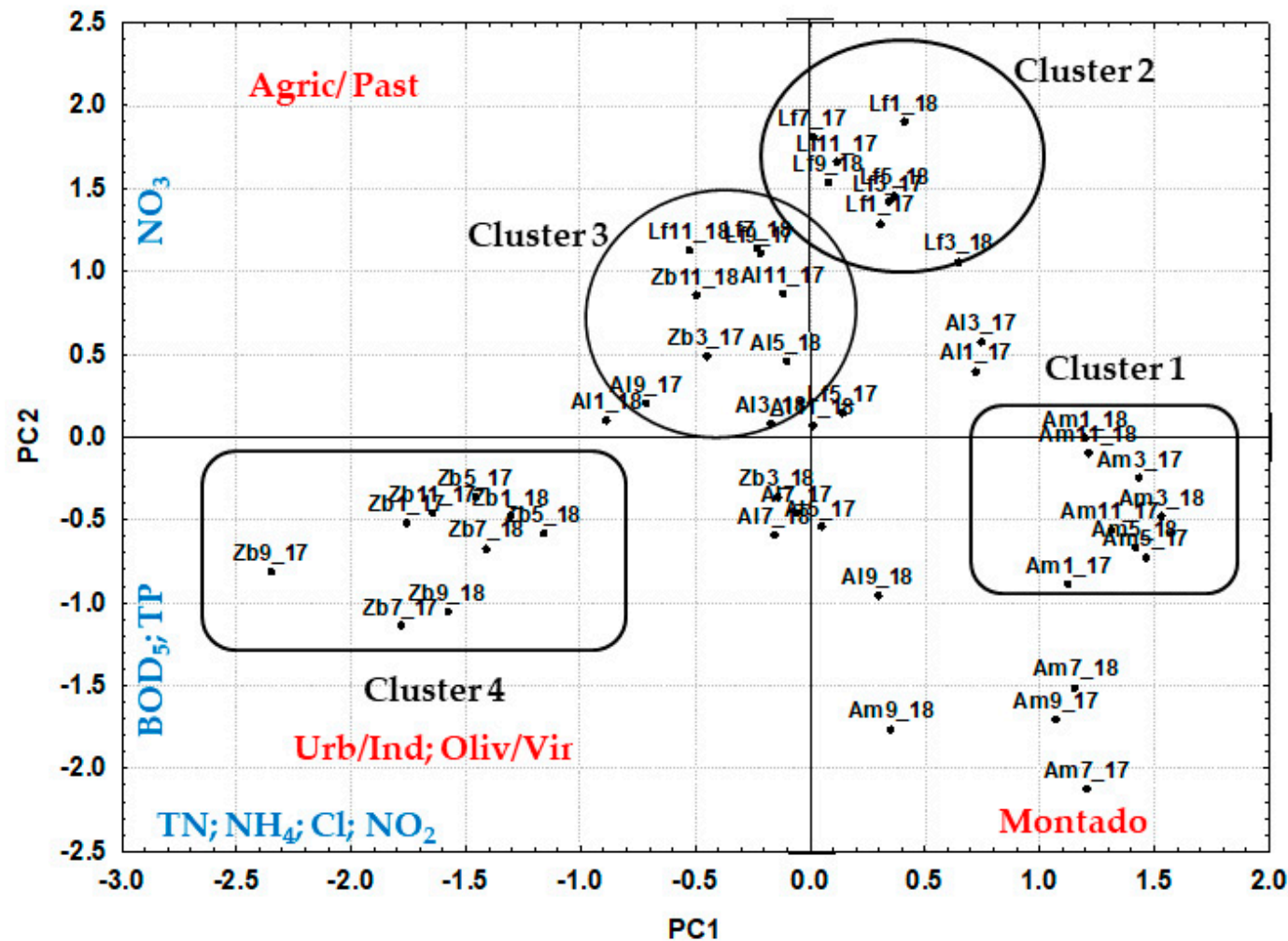

Figure 5. Scores of the water samples of streams, on the bidimensional plan defined by the first two principle components (PC) and parameters that most influence the explanation of each PC. In the figure are displayed the statistically significant clusters obtained with the Euclidean distance of (Dlink/Dmax) $\times 100<50$.

Figure 5 also evidences the four statistically significant groups obtained through the cluster analysis (Dlink/Dmax) $\times 100<50$. The samples that presented the best water quality were represented at the positive quadrant of $\mathrm{PC} 1$ and at the negative quadrant of $\mathrm{PC} 2$, integrating all samples from Amieira stream (Cluster 1), with high influence of the LULC Montado Class. Cluster 2 is represented in the positive quadrant of both PCs, integrating samples only from Lufecécit stream, with high concentrations of $\mathrm{NO}_{3}$ from agriculture and pasture activities. Cluster 3 represents the samples more influenced by agriculture and pasture activities, integrating samples from Álamos and Lucefécit streams. The negative quadrant of both PCs, displayed the samples with the worst water quality, grouped at Cluster 4, and belonging to the Zebro stream. These samples presented high amounts of organic descriptors and nutrients, explained by the action of olive grove and vineyards and urban/industrial classes at the streams.

\subsection{Sediment Characterization}

\subsubsection{Physico-Chemical Parameters}

Relatively to sediment grain size, important characteristic that controls the natural and anthropogenic components in the water-sediment systems [50], the results showed that the streams are mostly constituted by coarse particles-sand (Table 1). In general, the predominance of this granulometric fraction induces higher levels of percolation with lower adsorption potential for nutrients and trace

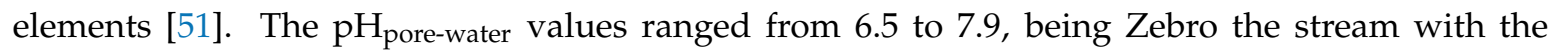

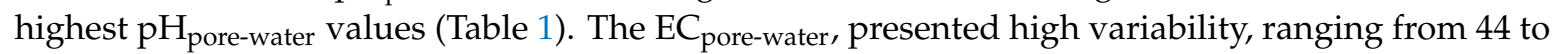
$1820 \mu \mathrm{sm}^{-1}$, with the highest values observed at Zebro (Table 1 ). The results evidence a positive correlation between $\mathrm{EC}_{\text {pore-water }}$ and olive groves, vineyards and orchards class $(R=0.46 ; p<0.05$; Table S4), as already observed in the water column. The link between LULC and $\mathrm{EC}_{\text {pore-water values is }}$ 
consistent with other studies that reported positive correlations between this parameter and intensive agriculture activities and urban classes [7,52]. Further, streams surficial sediments were characterized as inorganic, with mean percentages of organic matter (OM) contents less than 6 [53].

Table 1. Sediments main physicochemical characteristics (mean (min-max); $n=12$ ), in the studied streams: Lucefécit (Lf), Álamos (Al), Amieira (Am), and Zebro (Zb).

\begin{tabular}{ccccc}
\hline & Lf & Al & Am & Zb \\
\hline pH $_{\text {pore-water }}$ & $7.5(6.9-7.9)$ & $7.5(6.8-7.9)$ & $7.3(6.5-7.9)$ & $7.6(6.6-7.9)$ \\
\hline EC $_{\text {pore-water }\left(\mu \mathbf{~ c m}^{-1}\right)}$ & $712(429-929)$ & $916(115-1259)$ & $532(44-791)$ & $1217(233-1820)$ \\
\hline OM (\%) & $5.7(1.6-39.0)$ & $1.2(0.6-3.6)$ & $3.42(1.4-12.1)$ & $4.6(1.4-5.9)$ \\
\hline \multicolumn{5}{c}{ Granulometric Fractions } \\
\hline Sand (\%) & 58.76 & 64.83 & 90.06 \\
\hline Silt (\%) & 31.01 & 25.27 & 2.77 & 4.27 \\
\hline Clay (\%) & 10.15 & 8.63 & 7.85 & 8.60 \\
\hline
\end{tabular}

Relatively to the nutrients, the sediments presented TN concentrations always under the severe effect level (SEL) of $0.48 \%$ (Figure 6), according to the Ontario sediment quality guidelines [54]. In contrast, the concentrations of TP, despite its high variability, surpassed the SEL value, $0.2 \%$, in most of the samples. This scenario is similar to what occurred in the water samples and in the reservoir [8], indicating that the load of TP is very high in the catchment.

\subsubsection{Potentially Toxic Metals}

The results displayed a high variability without a temporal and a spatial pattern (Figure 6), which together with the correlations observed among potentially toxic metals and LULC classes namely urban/industrial and olive groves, vineyards, and orchards (Table S4), support anthropogenic actions as the main sources of these elements into the streams sediments. The potentially toxic metals that surpassed the Canadian interim freshwater sediment quality guideline (ISQG) were Cu, $\mathrm{Ni}$, and $\mathrm{Cd}$, elements that may be able to induce continuously toxic effects to aquatic organisms. Copper is correlated with the urban/industrial class $(R=0.37 ; p<0.05)$. Lucefécit stream presented the highest concentrations of $\mathrm{Cu}$, generally higher than the ISQG (35.7 $\mathrm{mg} \mathrm{kg}^{-1}$; [55]). Nickel was the trace element that showed less variability over time, surpassing the sediment quality guideline (SQG; $15.9 \mathrm{mg} \mathrm{kg}^{-1}$; [56]), except at Álamos. The highest concentrations for this element was observed at Lucefécit (10.1-96.4 $\mathrm{mg} \mathrm{kg}^{-1}$ ). Cadmium showed concentrations higher than the ISQG $\left(0.6 \mathrm{mg} \mathrm{kg}^{-1}\right.$; [55]), in Amieira and Zebro during the dry-phase and in Lucefécit during the whole study.

\subsubsection{The Effect of Textural Properties and LULC on the Sediments Quality}

Principal component analysis/factor analysis of sediments samples allowed us to obtain two principal components explaining about $52 \%$ of the total variance of the data. Figure 7 shows the combined plot of scores and loadings on PC1 versus PC2, and the three statistically significant groups obtained through the cluster analysis (Dlink/Dmax) $\times 100<50$. The PC1 $(28 \%)$ represented the influence of physical proprieties namely grain size on the composition of sediments. The sediments parameters most influenced by this explanatory factor were $\mathrm{Ni}$ and $\mathrm{Cu}$ (with loadings $\geq 0.75$ ), followed by the $\mathrm{Pb}$ and TN (with loadings among 0.75-0.50), all of these parameters with a positive participation in the PC1. PC2 was characterized by LULC classes explaining 23\% of the variance and highly correlated with TP (positive participation). As for the three statistically significant clusters, the samples located in the positive quadrant of both PCs were grouped in Cluster 1, integrating samples from Zebro, most influenced by olive groves, vineyards and orchards and with high amounts of TP. The Cluster 2 grouped the samples from Amieira and Álamos, most constituted by sand particles, with low capacity of adsorption and higher rates of pollutant load transfer to the reservoir. The samples displayed in 
the positive quadrant of PC1 and negative quadrant of PC2, represent the samples that presented higher percentages of fine particles (silt and clay) and higher concentrations of $\mathrm{Ni}, \mathrm{Cu}$, and $\mathrm{Pb}$, and $\mathrm{TN}$, integrating Lucefécit samples (Cluster 3).
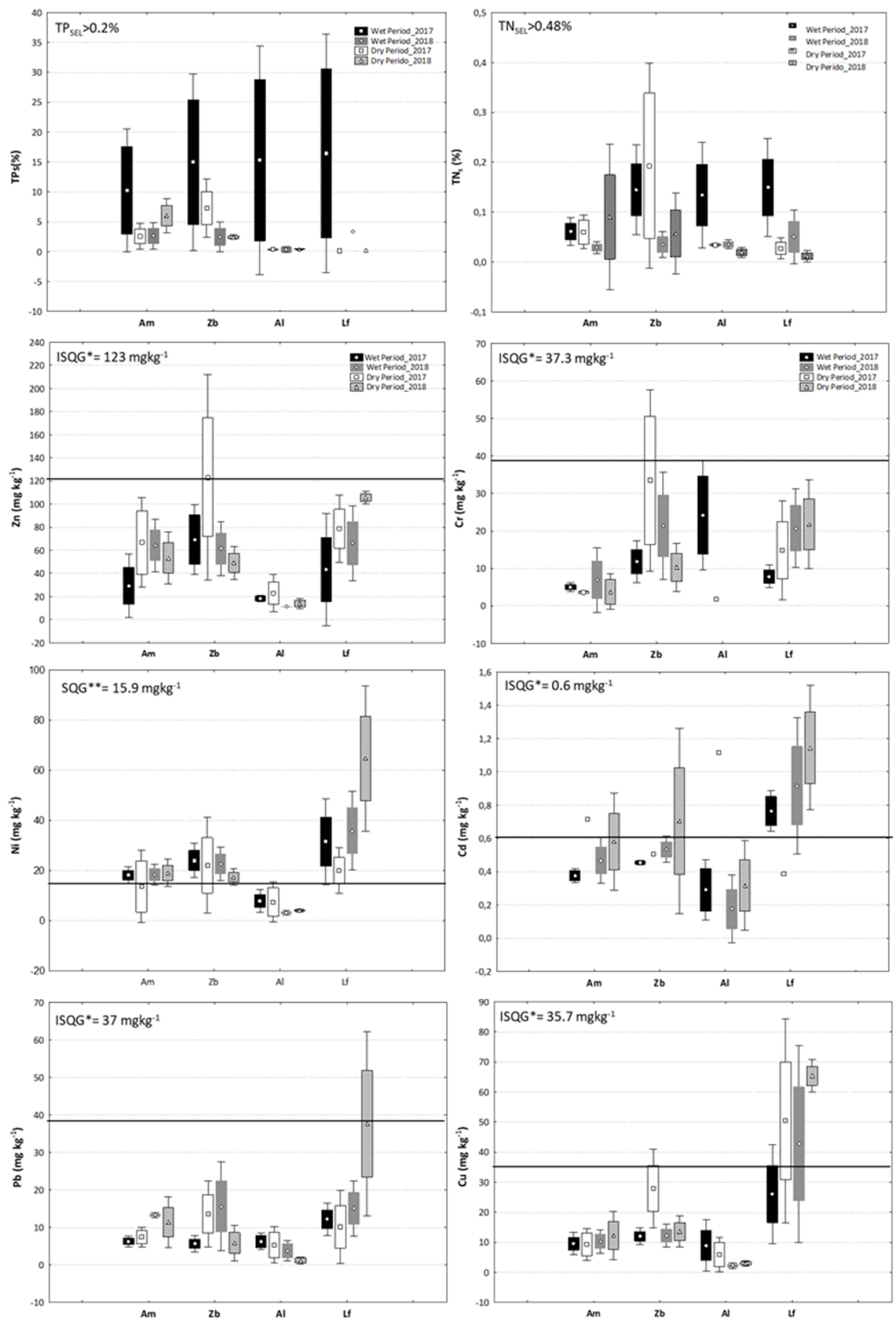

Figure 6. Variability of the nutrients and potential toxic trace elements at sediments. The mark across the box represents the mean, and the bottom and top of the box show the standard deviation. Guide levels were from: Severe Effect Level (SEL) Ontario Sediment Quality Guidelines [54]; Canadian Interim Freshwater Sediment Quality Guideline (ISQG) for the Protection of Aquatic Life [55]; Sediment Quality Guideline (SQG; [56]). 


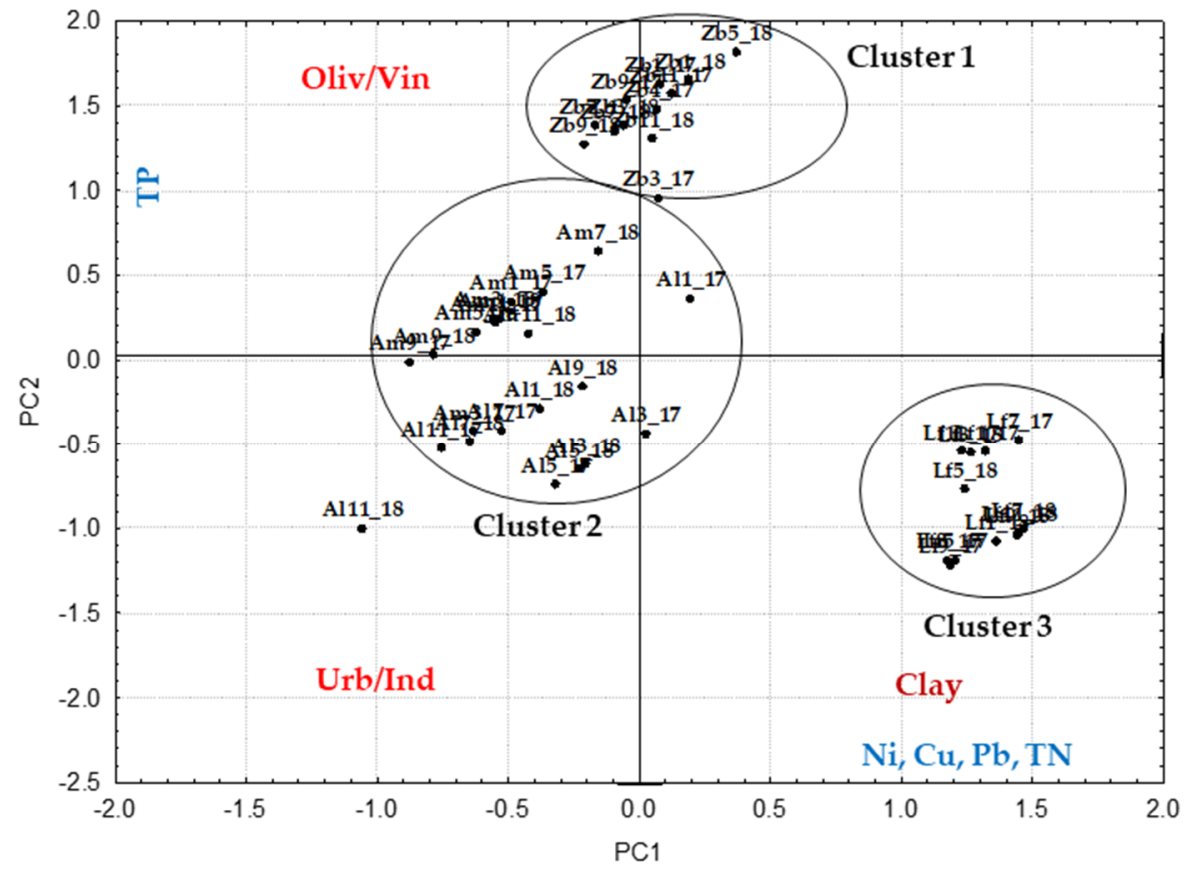

Figure 7. Scores of the sediments samples of streams, on the bidimensional plan defined by the first two principle components (PC) and parameters that most influence the explanation of each PC. At the figure are represented the statistically significant clusters obtained with the Euclidean distance of (Dlink/Dmax) $\times 100<50$.

\section{Discussion}

\subsection{LULC and Hydrogeomorphology Influence on the Physico-Chemical Characteristics of the Tributaries}

Relatively to the in situ parameters, the results showed high seasonal variability of temperature with similar spatial patterns, indicating that this parameter is more influenced by climate conditions such as air temperature, than by other anthropogenic or natural stressors as reported elsewhere [57]. The other parameter that showed high fluctuation and, in this case, not only seasonal but also spatial was the EC, being Zebro the stream that presented the highest values, during the dry season. The results showed a high influence of LULC in this parameter, being in agreement with other studies that reported the agriculture and urban/industrial classes as the main LULC responsible for the increase of this parameter in the water of streams [7,12,58]. Further, the increase of ion concentrations, which results in the increase of EC during dry seasons, may be justified by low flows, decrease of runoff, and high evaporation rates, causing the water volume reduction in permanent hydrologic regimes, and water cessation in temporary [59].

The $\mathrm{BOD}_{5}, \mathrm{COD}$, and TP were the parameters that most negative influenced the water quality, being the responsible for Zebro and Álamos not achieving the good ecological status, mainly during the dry seasons. The results point to the great influence of LULC classes in the concentrations of nutrients and organic descriptors in water, the urban/industrial and olive groves, vineyards, and orchard classes being the most polluting. Several studies already reported this linkage in different climate and LULC scenarios, as in rural-urban regions with a humid-subtropical climate (rural-urban fringe, Georgia Piedmont, USA; [7]), or in bare land and natural forest areas with tropical climate and intensive rainfall (Natural Forest of Córdoba Province, Argentine; [12]). Furthermore, Shi et al. [60], already stated that the urban class of LULC is the one with a major influence on the raise of the nitrogen and phosphorus forms in streams, via runoff, during and after precipitations events. Furthermore, Du et al. [61], in a study about the correlation of nutrients concentrations and LULC, identified the increment of intensive agriculture and population density as the major factor responsible for the raise of nitrogen and phosphorus in streams. Additionally, Ongley et al. [62] reported that 
intensive agriculture contributes with about $50 \%$ of the total contamination load to the streams, due to the inputs of inorganic fertilizers, organic manure, and pesticides. In addition to land uses, the hydrological regimes, very influenced by temporal conditions, also act in the concentrations of these parameters in water, being the temporary regimes (as occur in Zebro and Álamos) more sensitive to these anthropogenic conditions. Opposite, the results obtained in Amieira (stream with the best water quality) showed that, despite its temporary regime, the great percentage of agro-silvo-pastoral LULC may be a buffer to stop the runoff of contamination load. The results are in line with others that identified the forest and the riparian vegetation as the most important classes for the maintenance and improvement of the quality of water in streams, acting as a buffer to the pollution processes at the water body, and decreasing the soil erosion [63].

The assessment of sediment characteristics is essential for the whole analysis of the water quality, and for the evaluation of pollutant load transfer into a reservoir, being crucial in the establishment of management actions to preserve the aquatic environment. Hence, the sediments results reveled a great spatial and seasonal variability, being the granulometry and the LULC conditions, the great responsible for the concentrations of nutrients and potentially toxic metals observed. The streams sediments were mostly constituted by sand particles, as already observed in the upper part of Alqueva reservoir, near the border with Spain $[8,28]$. In general, the sediments presented low organic matter contents $(\mathrm{OM} ; \%)$ when compared with previous studies conducted in the Guadiana River Watershed [64,65]. The values detected in the present study were like those found at the upper part of Alqueva reservoir [8]. The presence of $\mathrm{OM}$ is one of the main factors responsible for the adsorption/accumulation of chemical elements to the sediments, which is corroborated by the positive correlations obtained with $\mathrm{TP}, \mathrm{TN}$, $\mathrm{Ni}, \mathrm{Cu}, \mathrm{Pb}, \mathrm{Cr}, \mathrm{Zn}$, a fact that was also reported for sediments from the Alqueva reservoir [8]. In fact, Lucefécit presented the highest amounts of potentially toxic metals, which could be justified by the highest percentages of fine particles (silt $=31 \%$ and clay $=10 \%$ ) and OM contents (3.6-39.3\%). On the other hand, Lucefécit drainage area is distinguished from the others because the urban/industrial land cover class is not limited to urban pollution but includes also industrial activities that may be related with the higher trace elements contamination. On the contrary, and despite the fact that Zebro presented highest contamination levels in the water column, the characteristics of its sediments, with a high percentage of coarse materials ( $87.89 \%$ sand), and low organic matter percentages, do not facilitate the adsorption of nutrients and hazardous substances onto the sediments. Relatively to the potentially toxic metals the results showed that the sediments were contaminated with $\mathrm{Cu}, \mathrm{Ni}$, and $\mathrm{Cd}$. Nickel surpassed its ISQG in at most of the streams, followed by $\mathrm{Cd}$ and $\mathrm{Cu}$. At previous studies at the Guadiana Watershed, including at Alqueva reservoir, reported that $\mathrm{Cd}$ was the most widespread element in the sediments and $\mathrm{Cu}$ was the element responsible for the polluted status of the sediments collected in the reservoir areas of Lucefécit and Álamos. Both elements have as main pollution sources the wastewaters discharge, road traffic and agriculture activities. Furthermore, Ni was the trace element less influenced by anthropic actions, with less variability and its concentrations being justified mainly by the geological characteristics of the basin $[31,66]$.

The importance of LULC, hydrological regimes, and granulometric proprieties was highlighted in the multivariate analysis, showing classes as urban/industrial and olive groves, vineyards, and orchards, fine particles of sediments, and flow (temporary regime) the main explicative factors of the presence of nutrients, organic descriptors, and potentially toxic metals in the Guadiana streams. Analysis and remarks already reported in different studies, such as at the Dan River Watershed, at China [61], at the Altamaha, and Savannah River watersheds, at State of Georgia [7], and at the Siriri River basin, Brazil [67].

\subsection{Influence of the Tributaries on the Water Quality of Reservoirs}

The influence of the transfer of nutrients, organic descriptors and potentially toxic metals from tributaries to the downstream reservoir was assessed. In general, results agree with what was previously observed in the Alqueva reservoir [8], evidencing a similar chemical pattern for some of the parameters 
assessed, and supporting the possible influence of these tributaries on the water quality of the reservoir. Relatively to nutrients, previous studies in the Alqueva reservoir, reported TN concentrations lower than the observed in the tributaries, but also suggestive of the stand-up of the nitrogen content in the watershed $[8,20]$. Similar results were also observed for $\mathrm{NO}_{3}$ and $\mathrm{NH}_{4}$, which have been increasing over time $[8,19,20]$. TP is the nutrient that is causing the highest stress in the Guadiana catchment, and that may be transported into the reservoir from the tributaries. This statement is supported by: (1) the high amount of TP in the water and sediments of the streams; (2) the high variability of the observed TP concentrations; and (3) the opposite trend of the TP concentrations among tributaries and the respective Alqueva areas [8]; unpublished results. Furthermore, and regarding the speed up of the eutrophication process that was reported for the Alqueva reservoir $[8,19]$, most of the tributaries presented high pollution rates with concentrations of TN $>1.5 \mathrm{mg} \mathrm{L}^{-1}$ and TP $>0.075 \mathrm{mg} \mathrm{L}^{-1}$, values established by Dodds et al. [68] to characterize eutrophic waters.

Among the potentially toxic elements analyzed in the studied streams, Cd probably was the mostly transferred element to the Alqueva reservoir, due to its characteristics, namely the great bioavailability, being the most mobile metal, and its high anthropic enrichment factor (EF) at the Guadiana watershed [31].

Further, the results indicate that the contamination load at Zebro and Álamos may be a possible source of contamination for Montante and Mourão areas (extents of the Alqueva reservoir where those streams directly drain). In fact, the tributaries that may be exerting the greatest pressure in the reservoir were Zebro and Álamos, due to their LULC, with the increment of nutrients, organic descriptors and potentially toxic metals, which are concentrated during the dry phase and further transferred to the reservoir in the beginning of the rainfall period, with the flow resumption. This process was facilitated by the granulometric proprieties (mostly constituted by coarse materials) and by the low OM contents, important factors for the low capacity to adsorb the elements in the sediments of streams, stimulating the pollutants loads transfer.

Henceforth, in addition to temporal and LULC scales, it is important to assess the hydrogeomorphological characteristics of streams for a better understanding of the possible pollution loads that may be transferred to the watercourses or reservoirs downstream. In fact, streams with an intermittent flow regime (increasingly important in the Mediterranean region), influence the water quality downstream depending on their flow characteristics and on the textural characteristics of their sediments. The intermittent regime promotes the accumulation of organic matter and nutrients on the stream bed (in the dry-phase), with the transfer of higher amounts of pollutant loads downstream, during a specific temporal period (wet period). Additionally, for an integrative analysis, the sediments textural properties must be evaluated. In fact, when stream sediments are mostly constituted by sand, the pollutants are not easily adsorbed and, most of them are probably transferred. Contrariwise, streams presenting sediments mostly constituted by fine particles, with high organic matter contents, easily adsorb nutrients and potentially toxic trace elements, avoiding their transfer downstream.

\section{Conclusions}

Stream water characteristics in the Guadiana River catchment displayed significant spatial and temporal variability. The results showed temporal differences in the linkage among LULC and water quality, pointing to the importance of several spatial and temporal scales to understand the impacts of anthropic actions on catchment ecosystem services.

The water quality of the streams was significantly influenced by seasonality and LULC, which was more obvious during the wet period. The study highlighted that the agro-silvo-pastoral land cover (Montado), a class characteristic of the Mediterranean region, has an important positive effect on water quality, acting as a buffer to the contamination of the streams. Contrariwise, the intensive agricultural and urban LULC areas may contribute to the decline of water quality.

Results pointed to the sensitivity of intermittent regimes to loads of pollutants, being movers for its transfer to downstream reservoirs. So, it is urgent to stop the increase of agriculture intensification in 
the Guadiana watershed, due to the impairment of these ecosystems and to the increment of pollution sources for the reservoirs.

The results highlight that the comprehension of the relationship between water quality, LULC, together with hydrogeomorphology conditions are essential tools for the improvement of the scientific knowledge about the main stressors at the Mediterranean region and the role of temporary regimes at its catchments. These results may be useful for a better and more specific management plan of the Guadiana watershed, which may be included in the next version of the River Basin Management Plan in 2021.

The increase, in the region, of temporary streams and its high sensitivity to pollution, makes urgent the development LULC policies to protect these ecosystems and improve its ecological status. Hence, policies that stop the intensification of agriculture activities, and encourage the creation of more areas of Montado, may be one of the best options for the preservation of this type of aquatic ecosystems.

Supplementary Materials: The following are available online at http://www.mdpi.com/2073-4441/12/10/2665/s1. Table S1. Main characteristics observed: flow conditions, dominant macrophytes, bank width, channel width, water depth. Legend for dates: the letters represent the month (Jn: January; Mr: March; M: May; Jl: July; Sp: September; Nv: November); the numbers indicate the year of observations and sampling (17:2017; 18:2018); Table S2. Adopted land cover categories and CORINE Land Cover (CLS) inventory classes present in the study area that integrates each broader category; Table S3. Spearman on ranks correlation coefficients between land cover classes and water physicochemical parameters in the four tributary studies (marked correlations in bold are significant at: $p<0.05 ; n=32$ ); Table S4. Spearman on ranks coefficients between land cover classes and sediments physicochemical parameters and potentially toxic metals in the four tributaries assessed (marked coefficients in bold are significant at: $p<0.05 ; n=34$ ).

Author Contributions: Conceptualization, P.P.; Investigation, S.F., A.L., C.M., A.P., M.H.N., A.R. and M.P.; Supervision, P.P.; Writing—original draft, P.P., M.H.N., M.M. and M.J.C.; Writing-review \& editing, P.P., M.H.N., M.M., M.J.C. and P.A. All authors have read and agreed to the published version of the manuscript.

Funding: The present research is co-funded by the European Union through the European Regional Development Fund, included in the COMPETE 2020 (Operational Program Competitiveness and Internationalization) through the ICT project (UIDB/04683/2020) with the reference POCI-01-0145-FEDER-007690, the ALOP project (ALT20-03-0145-FEDER-000004), and through the Engage SKA (POCI-01-0145-FEDER-022217) and by the European Union through the EU FP7 project SOLUTIONS (603437).

Acknowledgments: The authors thank the European Commission Copernicus Program for Copernicus Land Monitoring Service products, as well as the Ministry of Economy, Trade, and Industry (METI) of Japan and the United States National Aeronautics and Space Administration (NASA) for ASTER GDEM data, both used in this study.

Conflicts of Interest: The authors declare no conflict of interest.

\section{References}

1. Ahtiainen, H.; Öhman, M.C. Ecosystem Services in the Baltic Sea: Valuation of Marine and Coastal Ecosystem Services in the Baltic Sea; Nordic Council of Ministers: Copenhagen, Denmark, 2014.

2. Costanza, R.; d'Arge, R.; de Groot, R.; Farber, S.; Grasso, M.; Hannon, B.; Limburg, K.; Naeem, S.; O’Neill, R.V.; Paruelo, J.; et al. The value of the world's ecosystem services and natural capital. Nature 1997, 387, $253-260$. [CrossRef]

3. Tagliapietra, D.; Povilanskas, R.; Razinkovas-Baziukas, A.; Tamin, J. Emerald growth: A new framework concept for managing ecological quality and ecosystem services of transitional waters. Water (Switzerland) 2020, 12, 894. [CrossRef]

4. Arenas-Sánchez, A.; Rico, A.; Vighi, M. Effects of water scarcity and chemical pollution in aquatic ecosystems: State of the art. Sci. Total Environ. 2016, 572, 390-403. [CrossRef] [PubMed]

5. Field, C.B.; Barros, V.; Stocker, T.F.; Qin, D.; Dokken, D.J.; Ebi, K.L.; Mastrandrea, M.D.; Mach, K.J.; Plattner, G.-K.; Allen, S.K.; et al. Managing the Risks of Extreme Events and Disasters to Advance Climate Change Adapt; Cambridge University Press: Cambridge, UK, 2012.

6. IPCC. Climate Change 2014: Synthesis Report. Contribution of Working Groups I, II and III to the Fifth Assessment Report of the Intergovernmental Panel on Climate Change; Core Writing Team, Pachauri, R.K., Meyer, L.A., Eds.; IPCC: Geneva, Switzerland, 2014. 
7. Ignatius, A.R.; Rasmussen, T.C. Small reservoir effects on headwater water quality in the rural-urban fringe, Georgia Piedmont, USA. J. Hydrol. Reg. Stud. 2016, 8, 145-161. [CrossRef]

8. Palma, P.; Ledo, L.; Soares, S.; Barbosa, I.R.; Alvarenga, P. Spatial and temporal variability of the water and sediments quality in the alqueva reservoir (Guadiana Basin; Southern Portugal). Sci. Total Environ. 2014, 470, 780-790. [CrossRef]

9. Tan, X.; Yu, X.; Cai, L.; Wang, J.; Peng, J. Microplastics and associated PAHs in surface water from the Feilaixia Reservoir in the Beijiang River, China. Chemosphere 2019, 221, 834-840. [CrossRef]

10. Terechovs, A.K.E.; Ansari, A.J.; McDonald, J.A.; Khan, S.J.; Hai, F.I.; Knott, N.A.; Zhou, J.; Nghiem, L.D. Occurrence and bioconcentration of micropollutants in Silver Perch (Bidyanus bidyanus) in a reclaimed water reservoir. Sci. Total Environ. 2019, 650, 585-593. [CrossRef]

11. Khan, M.B.; Dai, X.; Ni, Q.; Zhang, C.; Cui, X.; Lu, M.; Deng, M.; Yang, X.; He, Z. Toxic Metal Pollution and Ecological Risk Assessment in Sediments of Water Reservoirs in Southeast China. Soil Sediment Contam. 2019, 28, 695-715. [CrossRef]

12. Bonansea, M.; Ledesma, C.; Rodriguez, M.C. Assessing the impact of land use and land cover on water quality in the watershed of a reservoir. Appl. Ecol. Environ. Res. 2016, 14, 447-456. [CrossRef]

13. Han, C.; Zheng, B.; Qin, Y.; Ma, Y.; Yang, C.; Liu, Z.; Cao, W.; Chi, M. Impact of upstream river inputs and reservoir operation on phosphorus fractions in water-particulate phases in the Three Gorges Reservoir. Sci. Total Environ. 2018, 610, 1546-1556. [CrossRef]

14. Woldeab, B.; Ambelu, A.; Mereta, S.T.; Beyene, A. Effect of watershed land use on tributaries' water quality in the east African Highland. Environ. Monit. Assess. 2019, 191, 36. [CrossRef] [PubMed]

15. Pullanikkatil, D.; Palamuleni, L.; Ruhiiga, T. Impact of land use on water quality in the Likangala catchment, southern Malawi D Pullanikkatil, LG Palamuleni \& TM Ruhiiga AFRICAN JOURNAL OF AQUATIC SCIENCE. Afr. J. Aquat. Sci. 2015, 40, 277-286. [CrossRef]

16. Mello, K.; Valente, R.A.; Randhir, T.O.; Santos, A.C.A.; Vettorazzia, C.A. Effects of land use and land cover on water quality of low-order streams in Southeastern Brazil: Watershed versus riparian zone. Catena 2018, 167, 130-138. [CrossRef]

17. Hering, D.; Carvalho, L.; Argillier, C.; Beklioglu, M.; Borja, A.; Cardoso, A.C.; Duel, H.; Ferreira, T.; Globevnik, L.; Hanganu, J.; et al. Managing aquatic ecosystems and water resources under multiple stress-An introduction to the MARS project. Sci. Total Environ. 2015, 503, 10-21. [CrossRef] [PubMed]

18. Canuto, N.; Ramos, T.B.; Oliveira, A.R.; Simionesei, L.; Basso, M.; Neves, R. Influence of reservoir management on Guadiana streamflow regime. J. Hydrol. Reg. Stud. 2019, 25, 100628. [CrossRef]

19. Morais, M.M.; Serafim, A.M.; Pinto, P.; Ilhéu, A.; Ruivo, M. Reservoir and River Basin Management. Exchange of Experiences from Brazil, Portugal and Germany; Univerlagtu: Berlin, Germany, 2007.

20. Palma, P.; Alvarenga, P.; Palma, V.L.; Fernandes, R.M.; Soares, A.M.V.M.; Barbosa, I.R. Assessment of anthropogenic sources of water pollution using multivariate statistical techniques: A case study of the Alqueva's reservoir, Portugal. Environ. Monit. Assess. 2010, 165, 539-552. [CrossRef] [PubMed]

21. Diogo, P.A.; Fonseca, M.; Coelho, P.S.; Mateus, N.S.; Almeida, M.C.; Rodrigues, A.C. Reservoir phosphorous sources evaluation and water quality modeling in a transboundary watershed. Desalination 2008, 226, 200-214. [CrossRef]

22. Chícharo, L.; Chícharo, M.A.; Ben-Hamadou, R. Use of a hydrotechnical infrastructure (Alqueva Dam) to regulate planktonic assemblages in the Guadiana estuary: Basis for sustainable water and ecosystem services management. Estuar. Coast. Shelf Sci. 2006, 70, 3-18. [CrossRef]

23. Collares-Pereira, M.J.; Cowx, I.G.; Ribeiro, F.; Rodrigues, J.A.; Rogado, L. Threats imposed by water resource development schemes on the conservation of endangered fish species in the Guadiana River Basin in Portugal. Fish. Manag. Ecol. 2000, 7, 167-178. [CrossRef]

24. Filipe, A.F.; Marques, T.A.; Tiago, P.; Ribeiro, F.; da Costa, L.M.; Cowx, I.G.; Collares-Pereira, M.J.; Collares-Pereira, M.J. Selection of Priority Areas for Fish Conservation in Guadiana River Basin, Iberian Peninsula. Conserv. Biol. 2004, 18, 189-200. [CrossRef]

25. Galvão, H.; Reis, M.; Valério, E.; Domingues, R.; Costa, C.; Lourenço, D.; Condinho, S.; Miguel, R.; Barbosa, A.; Gago, C.; et al. Cyanobacterial blooms in natural waters in southern Portugal: A water management perspective. Aquat. Microb. Ecol. 2008, 53, 129-140. [CrossRef] 
26. Palma, P.; López-Orozco, R.; Lourinha, C.; Oropesa, A.L.; Novais, M.H.; Alvarenga, P. Assessment of the environmental impact of an abandoned mine using an integrative approach: A case-study of the "Las Musas" mine (Extremadura, Spain). Sci. Total Environ. 2019, 659, 84-94. [CrossRef] [PubMed]

27. Valério, E.; Faria, N.; Paulino, S.; Pereira, P. Seasonal variation of phytoplankton and cyanobacteria composition and associated microcystins in six Portuguese freshwater reservoirs. Ann. Limnol. Int. J. Limnol. 2008, 44, 189-196. [CrossRef]

28. Palma, P.; Köck-Schulmeyer, M.; Alvarenga, P.; Ledo, L.; de Alda, M.L.; Barceló, D. Occurrence and potential risk of currently used pesticides in sediments of the Alqueva reservoir (Guadiana Basin). Environ. Sci. Pollut. Res. 2015, 22, 7665-7675. [CrossRef]

29. Palma, P.; Köck-Schulmeyer, M.; Alvarenga, P.; Ledo, L.; Barbosa, I.R.; López de Alda, M.; Barceló, D. Risk assessment of pesticides detected in surface water of the Alqueva reservoir (Guadiana basin, southern of Portugal). Sci. Total Environ. 2014, 488, 208-219. [CrossRef]

30. Palma, P.; Kuster, M.; Alvarenga, P.; Palma, V.L.; Fernandes, R.M.; Soares, A.M.V.M.; López de Alda, M.J.; Barceló, D.; Barbosa, I.R. Risk assessment of representative and priority pesticides, in surface water of the Alqueva reservoir (South of Portugal) using on-line solid phase extraction-liquid chromatography-tandem mass spectrometry. Environ. Int. 2009, 35, 545-551. [CrossRef]

31. Palma, P.; Ledo, L.; Alvarenga, P. Assessment of trace element pollution and its environmental risk to freshwater sediments influenced by anthropogenic contributions: The case study of Alqueva reservoir (Guadiana Basin). Catena 2015, 128, 174-184. [CrossRef]

32. Iakunin, M.; Salgado, R.; Potes, M. Breeze effects at a large artificial lake: Summer case study. Hydrol. Earth Syst. Sci. 2018, 22, 5191-5210. [CrossRef]

33. Potes, M.; Costa, M.J.; da Silva, J.C.B.; Silva, A.M.; Morais, M. Remote sensing of water quality parameters over Alqueva Reservoir in the south of Portugal. Int. J. Remote Sens. 2011, 32, 3373-3388. [CrossRef]

34. Palma, P.; Ledo, L.; Alvarenga, P. Ecotoxicological endpoints, are they useful tools to support ecological status assessment in strongly modified water bodies? Sci. Total Environ. 2016, 541, 119-129. [CrossRef] [PubMed]

35. Palma, P.; Ledo, L.; Soares, S.; Barbosa, I.R.; Alvarenga, P. Integrated environmental assessment of freshwater sediments: A chemical and ecotoxicological approach at the Alqueva reservoir. Environ. Geochem. Health 2014, 36, 209-223. [CrossRef]

36. APA (Agência Portuguesa do Ambiente) Plano de gestão de região hidrográfica 2016/2021. Parte 2. Caracterização e diagnóstico, Anexo IV. 2016. Available online: https://apambiente.pt/_zdata/Politicas/Agua/ PlaneamentoeGestao/PGRH/2016-021/PTRH7/PGRH7_Parte5_AnexoII_1.pdf (accessed on 10 July 2020).

37. Silva, Á.; de Lima, M.I.P.; Santo, F.E.; Pires, V. Assessing changes in drought and wetness episodes in drainage basins using the Standardized Precipitation Index. Bodenkultur 2014, 65, 31-37.

38. Potes, M.; Salgado, R.; Costa, M.J.; Morais, M.; Bortoli, D.; Kostadinov, I.; Mammarella, I. Lake-atmosphere interactions at Alqueva reservoir: A case study in the summer of 2014. Tellus A Dyn. Meteorol. Oceanogr. 2017, 69, 1272787. [CrossRef]

39. IPMA. Situação de Seca Meteorológica. Available online: https://www.ipma.pt/resources.www/docs/im. publicacoes/edicoes.online/20180406/pryhFYgszRoHXedniacN/cli_20180331_20180331_sec_mm_co_pt.pdf (accessed on 10 July 2020).

40. Godinho, S.; Guiomar, N.; Machado, R.; Santos, P.; Sá-Sousa, P.; Fernandes, J.P.; Neves, N.; Pinto-Correia, T. Assessment of environment, land management, and spatial variables on recent changes in montado land cover in southern Portugal. Agrofor. Syst. 2016, 90, 177-192. [CrossRef]

41. APHA (America Public Health Association). Standard Methods for the Examination of Water and Wastewater, 23rd ed.; America Public Health Association: New York, NY, USA, 2017.

42. USEPA. Methods for Collection, Storage and Manipulation of Sediments for Chemical and Toxicological Analyses: Tech. Man; EPA-823-B-01-002; EPA Region V.: Chicago, IL, USA, 2001.

43. LNEC (Laboratório Nacional de Engenharia Civil). E 196-Solos. Análise Granulométrica; LNEC: Lisboa, Portugal, 1966.

44. ISO (International Organization for Standardization). ISO 11466: Soil Quality_Extraction of Trace Elements Soluble in Aqua Regia; ISO: Geneve, Switzerland, 1995.

45. Simeonov, V.; Stratis, J.A.; Samara, C.; Zachariadis, G.; Voutsa, D.; Anthemidis, A.; Sofoniou, M.; Kouimtzis, T. Assessment of the surface water quality in Northern Greece. Water Res. 2003, 37, 4119-4124. [CrossRef] 
46. Alberto, W.D.; Del Pilar, D.M.; Valeria, A.M.; Fabiana, P.S.; Cecilia, H.A.; De Los Angeles, B.M. Pattern recognition techniques for the evaluation of spatial and temporal variations in water quality. A case study: Suquía River Basin (Cordoba-Argentina). Water Res. 2001, 35, 2881-2894. [CrossRef]

47. Agencia Portuguesa Ambiente (APA). Plano de Gestão de Região Hidrográfica 2016/2021: Região Hidrográfica do Guadiana (RH7); Agencia Portuguesa Ambiente (APA): Lisboa, Portugal, 2016.

48. Palma, P.; Matos, C.; Alvarenga, P.; Köck-Schulmeyer, M.; Simões, I.; Barceló, D.; López de Alda, M.J. Ecological and ecotoxicological responses in the assessment of the ecological status of freshwater systems: A case-study of the temporary stream Brejo of Cagarrão (South of Portugal). Sci. Total Environ. 2018, 634, 394-406. [CrossRef]

49. Instituto da Água. Relatório Síntese Sobre a Caracterização das Regiões Hidrográficas Prevista na Directiva-Quadro da Água; Instituto da Água: Lisboa, Portugal, 2005; p. 163. Available online: https://www.apambiente.pt/dqa/ assets/relatorio_artigo_5_pt.pdf (accessed on 16 July 2020).

50. Rowlatt, S.M.; Lovell, D.R. Lead, zinc and chromium in sediments around England and Wales. Mar. Pollut. Bull. 1994, 28, 324-329. [CrossRef]

51. Oliveira, A.; Palma, C.; Valença, M. Heavy metal distribution in surface sediments from the continental shelf adjacent to Nazaré canyon. Deep Sea Res. Part II Top. Stud. Oceanogr. 2011, 58, 2420-2432. [CrossRef]

52. Petersen, J.C.; Justus, B.G.; Meredith, B.J. Effects of Land Use, Stream Habitat, and Water Quality on Biological Communities of Wadeable Streams in the Illinois River Basin of Arkansas, 2011 and 2012; US Geological Survey No.2014-5009: Reston, VA, USA, 2014.

53. Cardoso-Silva, S.; de Lima Ferreira, P.A.; Figueira, R.C.L.; da Silva, D.C.V.R.; Moschini-Carlos, V.; Pompêo, M.L.M. Factors that control the spatial and temporal distributions of phosphorus, nitrogen, and carbon in the sediments of a tropical reservoir. Environ. Sci. Pollut. Res. 2018, 25, 31776-31789. [CrossRef]

54. Fletcher, R.; Welsh, P.F.P. Guidelines for Identify, Assessing and Managing Contaminated Sediments in Ontario: An Integrated Approach; Water Resources Branch: Toronto, ON, Canada, 2008.

55. CCME-Canadian Council of Ministers for the Environment. Canadian Sediment Quality Guidelines for the Protection of Aquatic life: Summary Tables; CCME: Winnipeg, MB, Canada, 2002. Available online: http://st-ts.ccme.ca/ (accessed on 12 July 2020).

56. Long, E.R.; Macdonald, D.D.; Smith, S.L.; Calder, F.D. Incidence of adverse biological effects within ranges of chemical concentrations in marine and estuarine sediments. Environ. Manag. 1995, 19, 81-97. [CrossRef]

57. Nunes, J.P.; Jacinto, R.; Keizer, J.J. Combined impacts of climate and socio-economic scenarios on irrigation water availability for a dry Mediterranean reservoir. Sci. Total Environ. 2017, 584, 219-233. [CrossRef] [PubMed]

58. Rodrigues, V.; Estrany, J.; Ranzini, M.; de Cicco, V.; Martín-Benito, J.M.T.; Hedo, J.; Lucas-Borja, M.E. Effects of land use and seasonality on stream water quality in a small tropical catchment: The headwater of Córrego Água Limpa, São Paulo (Brazil). Sci. Total Environ. 2018, 622, 1553-1561. [CrossRef]

59. Stephan, K.; Kellner, E.; Freedman, Z.; Kutta, E.; Kelly, C.; Hubbart, J.; Morrissey, E. Characterization of sub-watershed-scale stream chemistry regimes in an Appalachian mixed-land-use watershed. Environ. Monit. Assess. 2018, 190, 586. [CrossRef]

60. Shi, P.; Zhang, Y.; Li, Z.; Li, P.; Xu, G. Influence of land use and land cover patterns on seasonal water quality at multi-spatial scales. Catena 2017, 151, 182-190. [CrossRef]

61. Du, L.F.; Liu, J.; Li, S.J.; Li, X.R.; Yang, J.F.; Zhao, T.K.; Ma, M.T. Dynamic characteristics of nitrogen and phosphorus in the representative input tributaries of Miyun Reservoir. IOP Conf. Ser. Earth Environ. Sci. 2017, 82, 012084. [CrossRef]

62. Ongley, E.D.; Xiaolan, Z.; Tao, Y. Current status of agricultural and rural non-point source Pollution assessment in China. Environ. Pollut. 2010, 158, 1159-1168. [CrossRef]

63. Zhou, Y.; Xu, J.F.; Yin, W.; Ai, L.; Fang, N.F.; Tan, W.F.; Yan, F.L.; Shi, Z.H. Hydrological and environmental controls of the stream nitrate concentration and flux in a small agricultural watershed. J. Hydrol. 2017, 545, 355-366. [CrossRef]

64. Batista, M.J.; Abreu, M.M.; Locutura, J.; De Oliveira, D.; Matos, J.X.; Silva, C.; Bel-Lan, A.; Martins, L. Evaluation of trace elements mobility from soils to sediments between the Iberian Pyrite Belt and the Atlantic Ocean. J. Geochem. Explor. 2012, 123, 61-68. [CrossRef]

65. Fonseca, R.; Barriga, F.J.A.S.; Fyfe, W.S. Reversing desertification by using dam reservoir sediments as agriculture soils. Episodes 1998, 21, 218-224. [CrossRef] 
66. Mil-Homens, M.; Vale, C.; Raimundo, J.; Pereira, P.; Brito, P.; Caetano, M. Major factors influencing the elemental composition of surface estuarine sediments: The case of 15 estuaries in Portugal. Mar. Pollut. Bull. 2014, 84, 135-146. [CrossRef]

67. Cruz, M.A.S.; de Azevedo Gonçalves, A.; de Aragão, R.; de Amorim, J.R.A.; da Mota, P.V.M.; Srinivasan, V.S.; Garcia, C.A.B.; de Figueiredo, E.E. Spatial and seasonal variability of the water quality characteristics of a river in Northeast Brazil. Environ. Earth Sci. 2019, 78, 68. [CrossRef]

68. Dodds, W.K.; Jones, J.R.; Welch, E.B. Suggested classification of stream trophic state: Distributions of temperate stream types by chlorophyll, total nitrogen, and phosphorus. Water Res. 1998, 32, 1455-1462. [CrossRef]

(C) 2020 by the authors. Licensee MDPI, Basel, Switzerland. This article is an open access article distributed under the terms and conditions of the Creative Commons Attribution (CC BY) license (http://creativecommons.org/licenses/by/4.0/). 